UDC 37.017:004

DOI: https://doi.org/10.30839/2072-7941.2018.149674

\title{
EDUCATION AS A FACTOR OF CREATIVE PERSONALITY ESTABLISHMENT AND DEVELOPMENT IN INFORMATION SOCIETY
}

\author{
(C) NIKITENKO, V.O. \\ Zaporizhzhia State Engineering Academy (Zaporizhzhia, Ukraine) \\ E-mail: vitalina2006@ukr.net, ORCID 0000-0001-9588-7836
}

\begin{abstract}
The relevance of the study is that the analysis of education as a factor in the formation and development of a creative personality and the conditions conducive to the emergence of a "new creative class" is done. Formulation of the problem - the conceptualization of education as a factor in the formation and development of a creative personality, its main categories in terms of "creativity" and the demand of man as a creator of an innovative environment, based on a new level of interaction "man-society-education", changing the model of sociality. Analysis of recent research and publications. In the study, we rely on the phenomenon of creativity, which is studied in the works of V. Andruschenko, V. Beh, V. Voronkova, A. Kravchenko, S. Kutsepal, O. Kivlyuk, R. Olexenko. The main focus is on Richard Florida's work "Homo creatives: How the New Class Conquers the World" (Kyiv, 2018). The matrix of education as a factor in the formation and development of a creative personality focuses attention on the discourse thinking of the relationship "creative personality-education" and the influence of the information society on these relationships. Exemption of unexplored parts of the general problem - conceptualization of the concept of "creative personality" and its role in modern information society. At the heart of the study the conceptualization of the basic schemes of creativity and this is a scientific novelty. The epistemological character of the statement and the praxeological solution of this problem in favor of a creative person and education show that the society must have the necessary and sufficient resources for the reproduction of a creative person and its effective development that affects the social sphere of man. The basic material. The analysis of formation and development of the creative person as the main factor of education is carried out; the definition of "creative personality" is presented; it is proved that the creative component is the dominant factor necessary for solving problems of efficiency of all spheres of activity, including economic ones; conditions that contribute to the growth of the creative component in the future are analyzed ; It was found that it is a "creative social class" as a new class of information society. The object of research is the concept of a creative personality as a new social and cultural phenomenon. The subject of research is the influence of the information society on the formation and development of a creative personality. Methodology is a method of cultural creation, which provides an opportunity for the formation and development of a creative personality. Conclusions - the concept of education as a factor in the formation and development of a creative personality in the conditions of the information society is formed.
\end{abstract}

Key words: education, creative personality, creativity, competence, information society, "new creative class".

The problem is presented in general terms and its connection with important scientific or practical tasks. Relevance of research topic.
The matrix of education as a factor in the formation of a creative personality focuses attention on the discourse thinking of the relationship "creative personality-education", 
which is central to the whole of social philosophy and philosophy, pedagogy, cultural studies. The epistemological character of the statement of this problem and the praxeological solution of this problem in favor of a creative person and education shows that the society must have the necessary and sufficient resources for the reproduction of a creative person and its effective development that affects the social realm of man. Since the mid-1980s of the last century, creativity has emerged as an applied science, which intensions its research into the study of creativity and its relationship with education.

The social phenomenon of education as a factor in the formation of a creative personality, emerging in the context of the historical evolution of the scientific picture of the world, is today relevant in pedagogy, psychology, philosophy. The study of the peculiarities of the interaction of man and education began with the emergence of theories of technocratic culture as a synthesis of rational methods and procedures of technical knowledge, in conjunction with sociocultural features, socially necessary for managing the progress of technical progress, "the best satisfaction of needs" (Jevons, Menger), "the benefits of the consumption society", characterized by differentiation and specialization of social institutions, high level of industry, science and technology, market economy, urbanization, open system social mobility.

Analysis of the peculiarities of education as a factor in the formation of a creative individual shows that a creative person is an image used to capture all the diversity of historical and cultural traditions and innovations, activity factors and spiritual aspirations, ideological paradigms involved in the active processes of existence in correlation with socio-cultural activities of man.

The analysis of recent researches and publications, which initiated the solution of this problem, which is based on the authors

In the study, we rely on the phenomenon of creativity, which is studied in the works of $\mathrm{V}$. Andrushenko, V. Beh, V. Voronkova, A. Kravchenko, S. Kutsepal, O. Kivlyuk, R. Olexenko. The main focus is on Richard Florida's work "Homo creatives: How the New Class Conquers the World" (Kyiv, 2018). The part of the general problem which wasn't unsolved earlier. Formulation of the problem The matrix of education as a factor in the formation and development of a creative personality focuses attention on the discourse thinking of the relationship "creative personalityeducation" and the influence of the information society on these interrelations.

The purpose of scientific research is the conceptualization of education as a factor in the formation and development of a creative personality, its main categories in the dimension of "creativity" and the demand of man as a creator of an innovative environment, based on a new level of interaction "man-society-education", changing the model of sociality.

This goal is realized in a number of tasks:

- to analyze the formation and development of the creative 
personality as the main factor of education;

- to introduce the definition of "creative personality";

- to prove that the creative component is the dominant factor necessary for solving problems of efficiency of all spheres of activity, including economic ones;

- analyze the conditions that contribute to the growth of the creative component in the future;

- to identify what constitutes a "creative social class" as a new class of information society.

The object of research - the concept of a creative personality as a new social and cultural phenomenon and creativity class.

The subject of the research is the influence of the information society on the formation and development of a creative personality and creativeclass.

Methodology - methods of cultivating and synergetics, which provide an opportunity for the formation and development of a creative personality and the establishment of its inverse relationships [1, p. 267-271].

Formation of the creative class as a goal of modern education comes into being during its maturity, which shows that for the first time in the history of humanity we have to bring economic development in line with the development of human potential, which depends on the use of talents and creative potential and the acceleration of this process, by developing Smart -technology as a factor in the development of modern progress [2].
Now, in an era, where the driving factors of the economy are knowledge, innovation, creativity and human potential, the situation is different. Therefore, it is necessary to now create new, effective indicators of creativity of human potential as a matrix of modern innovation, information and technological education, than a gross domestic product, to achieve an overgrowth from the industrial to the creative era, which requires the formation of the concept of "creative age" [3, p.1625].

The supercritical nucleus of this era includes scientists, engineers, university professors, writers, artists, entertainers, actors, designers, architects, as well as those who are the "leaders of thoughts" of the present day, they are the writers, editors, prominent figures of culture and sign representatives our culture, researchers of think tanks, and other people who influence the way we feed our minds, "notes R.Florida [p. 55].

The highest level of creativity is the search for new design forms and designs that are easy to implement, extend and become useful, such as the development of software that can be "developed" and sold; creating a theorem or strategy that can be applied in a number of cases; writing music that can be played again and again [4, p.159-161].

Their work involves the search for these tasks and problems: it is not just something to construct better, but to construct something innovative and pragmatic. Outside of this group (core), the creative class includes "creative professionals" who work in a broad field of diverse industries that 
are characterized by a powerful component of knowledge, such as high technology, financial services, health and medicine, law, business management, etc.

These people are engaged in creative task solving, and in this activity they rely on the whole body of complex expert knowledge that allows them to cope with very specific tasks. In order to be able to do this, high-quality creative education is needed, and, consequently, a high level of human capital [16].

Consequently, the modern state should form innovative indicators of creative education, aimed at real growth, in order to achieve economic efficiency and social progress [5, p. 362-365], we must move from a senseless growth (Industrial Age) to a reasonable growth (Creative Age), based on the use of all human possibilities, of its talents, selfexpression as one of the most important human rights in the strategy of strengthening civil society $[14, \mathrm{p}$. 127-140].

One of the problems is the formation of creative education, which is based on reason, intelligence, development, innovation, knowledge, information. Creative education is experiencing the most difficult stage on which the choice of the main direction of development takes place. Creative education as the broadest synthesis of economic and humanitarian knowledge is intended to reveal the principles and laws of the noosphere culture. Creative education structures the constructs of a spiritual economy in which the economic behavior of an "economic person" should include the primacy of spiritual needs over material needs. The main function of creative thinking is to ensure the integral integrity, unity, safety and well-being of its citizens, which is provided through good management and effective management. Since it is always necessary to overcome the dissipative structures of creative education, an adaptive mechanism of the educational system should be developed at the expense of cooperative ties, organization of space in order not only to survive under various ideological influences, but also to withstand the destruction of the established society [6, p. 33-48].

First of all, creative thinking must be formed on the basis of creative management, based on the synergetic and non-linear vision of ways to overcome general civilization problems, in the context of which there is an alternative transition from an technogenic development model in which man opposes nature to a coevolutionary model of the existence of mankind, whose model focuses attention on the forum of noosociogenez. The noospheric concept of creative education means that education is defined by the sphere of reason (noosphere), morality and justice, is based on a scientific, rational and moral basis of justice, on noosphere approaches to the development of society [7, p. 233236].

The noosphere represents such a humanistic sphere of creative management in which management is implemented by a moral-just mind and a global integral intelligence. The criterion for the level of development and quality of human life is the 
creative values and knowledge of a person who lives in harmony with the surrounding nature and the natural environment. It is in the noosphere that systemic-synergetic synthesis of all components of creative development is achieved, not only in the very society, which acts as a noosphere-global entity, but also in its relations with nature, both terrestrial and cosmic [8, p. 219-225].

The penetration of creative education at all levels of social organization of society leads to a growing demand for qualified specialists. Thanks to information technology, every five years there is a doubling of global knowledge, and only half of this knowledge is demanded and, therefore, is of such value.

M. Castells, who sees in the information technologies the most important factor of social change, gives even greater importance to the information and technological component of the production of knowledge. The development of the Internet has led to a new type of division of labor in the service sector and, in general, to structural changes in the global labor market, in connection with which the demand was for creative education [9, p. 133148].

The information society needs highly skilled workers, that is, a highly skilled workforce needed, in particular for all branches of production - organization, planning, leadership, coordination of intellectual resources as the main value of the information society. In modern information society, science plays a leading role, as it is an intellectual force, as well as a basis for the development of neo-economics and information technology, the creation of new innovative technologies.

Science constitutes the intellectual environment of a society, on the basis of which a creative class of personnel is being prepared for various branches of production. In this regard, the organization of the education system of all levels, the work of scientific schools, the scientific infrastructure of which is created for decades [10, p. 251-2576].

The most important function of science, the "knowledge society", is the orientation in a complex nonlinear world, in which there are interconnections between the most diverse phenomena, all occurring in dynamics and changes, and within certain limits of stability there are bifurcations and catastrophes.

Over time, the spectrum of problems is expanding, covering all the new parties, requiring forecasting and modeling of events, assessing everything that is happening. That is why synergetics examines the regularities of ordering, the formation of structures in the most diverse creative systems, for which the same phenomena of self-organization are characteristic [11].

On the basis of synergetics an analysis of instability is given, feedback, bifurcation and disaster, as in the top complex systems, it is essentially impossible to regulate all the details of what is happening. Therefore, the control system in the "society of knowledge" cannot be centralized, but must be based on the principles that influence the 
development strategy and certain integral characteristics [12, p. 174].

Therefore, synergetics has received a particularly large impetus for development over the last quarter of a century and is successfully implemented in the information society. The noosphere path of development appears to be natural in the background of the rapid growth of science (as a collective mind) in all spheres of human activity.

The structure of knowledge management in a "smart society" and its information system must be based on science as the driving force of intellectual progress. The management of knowledge and competences is necessary: for the intellectual progress of the state (nation), the growth of the competitiveness of science in all spheres of society, for ensuring intellectual progress and in the future of the formation of intellectual civilization of the XXI century [13, p.134].

The big changes of our time, which are becoming more and more active, are happening due to explaining the role of creative education as a defining characteristic of progress and prosperity in the times of extraordinary technologies.

Creative education has begun to appreciate, and for the sake of support and encouragement, the whole system has spread, as more and more people are inclined to recognize the decisive role of education, the emergence of new technologies, new industries of new wealth [8, p. 222].

Creative education involves expressive mental activity, activity and patterns of behavior that should be cultivated both at the individual and at the social level. The creative ethos penetrates everywhere - in jobs, values, communities, and transforms our vision of ourselves, as well as of economic and political actors, and thus forms the core of our identities [15].

Creative education reflects creativity and, at the same time, enhances its role, as this requires an environment that supports creativity through social, economic and cultural stimuli [9, p. 144]. That is why creative education forms a new working environment, new lifestyles, new organizations that are critical to the production of technological creativity and commercial innovation. Therefore, creativity is a victory that contributes to the fulfillment of many functions of the new creative economic system.

\section{Conclusions}

Higher education and creative career intersect, but they are not the same. There are representatives of the creative class that do not have higher education (USA), so creativity is something more important than higher education, and formal education generally impedes creativity. At the same time, creativity affects wages.

Along with the creative class, the class of service workers grows, which is a response to the needs of the creative economy. The rise of the creative class is reflected in the powerful and significant shift in the values and norms that underlie individuality and self-expression, namely, the priority of "secularrational values" that govern politics, work, religion, family, contribute to prosperity, the development of 
creative industries and a powerful economic growth.

\section{REFERENCES}

1. Azhazha, M. A. (2006). Teoretyko-medolohichni zasady kontseptsiyi liudskoho kapitalu. Efektyvnist suchasnoho menedzhmentu orhanizatsiyi. Kharkiv: KhIMB, 267-271.

2. Brinolfsson, E., Makafi, E. (2016). Druha epokha mashyn: robota, prohres ta protsvitannia $\mathrm{v}$ chasy nadzvychainykh tekhnolohiy. Kyiv: FUND, 236.

3. Voronkova, V. H. (2018). Osvita postmodernu v umovakh post kolonializmu. Osvitniy dyskurs: Natsionalnyi pedahohichnyi universytet imeni M.P.Drahomanova, 5, 16-25.

4. Voronkova, V. H., Maksymeniuk, M. Yu., Nikitenko, V. O. (2017). Formation of noosphere world as the basis of information and innovation noosphere, noosphere economy and society. Hileia, 122, 159-162.

5. Kyvliuk, O. P. (2015). Socio-cultural phenomenon of modern education and science. Hileia, 101, 362-365.

6. Kyvliuk, O. P. (2013). Rol komunikatyvnoho resursu v konteksti hlobalizatsiynykh protsesiv. Hileia, 73, 149-150.

7. Fiurst, M., Trynks, Yu. (2018). U spivprtsai z Nikolausom Halmerom. Filosofiya. Kyiv: Instytut relihiinykh nauk sv. Tomy Akvinskoho, «Dukh i Litera», 544.

8. Melnyk, V. V. (2014). Hlobalizatsiia v kulturniy sferi: teoretyko-metodolohichnyi analiz. Hileia, 86, 219-225.

9. Melnyk, V. V. (2015). Ontolohycheskye, aksyolohycheskye y antropolohycheskye osnovanyia razvytyia sovremennoho myra. Hileia, 94, 143-148.

10. Nikitenko, V. (2016). Cultural and social competence creation in the process of english language study: information society aspect. Humanitarian Bulletin of the Zaporizhzhya State Engineering Academy, 67, 251-257.

11. Oleksenko, R. I. (2013). Filosofiya, mirovozzrenie i moral' sovremennogo predprinimatelya kak sostavnaya ekonomiko-social'nogo razvitiya obshchestva. Sociosfera, 1, 31-37.

12. Ryzhova, I. (2017). Smart - technologies as the factor of development of modern design. Humanitarnyi visnyk Zaporizkoi derzhavnoi inzhenernoi akademiyi, 69 (1), 174-183.

13. Ryzhova, I. (2011). Culture is the most fundamental way of human existence. Humanitarnyi visnyk Zaporizkoi derzhavnoi inzhenernoi akademiyi, 46, 126-134.

14. Sydorenko, S. V. (2012). Teoretyko-metodolohichni zasady hlobalnoho hromadianskoho suspilstva. Naukovi zapysky KUTEP, 13, 127-140.

15. Sosnin, O. V., Nikitenko, V. O., Maksymeniuk, M. Yu. (2017). Informaitsinokomunikatyvnyi menedzhment: zarubizhnyi i vitchyznianyi menedzhment. Kyiv: KPI im. Ihoria Sikorskoho, Vyd-vo «Politekhnika», 316.

16. Floryda, R. (2018). Homo creatives: Yak novyi klas zavoiovuie svit. Kyiv: Nash formyt, 432.

НІКІТЕНКО, В. О. - кандидат філософських наук, доцент кафедри українознавства i суспільно-філософських наук, Запорізька державна інженерна академія (Запоріжжя, Україна)

E-mail: vitalina2006@ukr.net, ORCID: 0000-0001-9588-7836

\section{ОСВІТА ЯК ЧИННИК СТАНОВЛЕННЯ І РОЗВИТКУ КРЕАТИВНОЇ ОСОБИСТОСТІ В УМОВАХ ІНФОРМАЦІЙНОГО СУСПІЛЬСТВА}

Анотація. Актуальність дослідження в тому, що проаналізовано освіту як чинник становлення і розвитку креативної особистості та умови, що сприяє появі «нового креативного класу». Постановка завдання - концептуалізація освіти як 
чинника становлення і розвитку креативної особистості, основних її категорій у вимірі «креативності» та витребуваності людини як креатора інноваційного середовища, в основі якого новий рівень взаємодії «людина-суспільство-освіта», що змінює моделі соціальності.

Аналіз останніх досліджень і публікацій. В дослідженні ми спираємося на феномен креативності, що досліджуються в роботах В.Андрущенка, В.Беха, В.Воронкової, А.Кравченко, С.Куцепал, О.Кивлюк, Р.Олексенка. Головна увага зосереджена на роботі Річарда Флориди «Ноmo creatives: Як новий клас завойовує світ» (Київ, 2018). Матриця освіти як чинника становлення і розвитку креативної особистості актуалізує увагу на дискурсосмисленні взаємовідносин «креативна особистість-освіта» та впливу інформаційного суспільства на ці взаємовідносини.

Виділення недосліджених частин загальної проблеми - концептуалізація поняття «креативна особистість» та іiї роль в сучасному інформаційному суспільстві.

В основі дослідження - концептуалізація базових схем креативності, що представляє собою наукову новизну. Епістемологічний характер постановки та праксеологічне вирішення даної проблеми на користь креативної людини та освіти свідчить, що соціум повинен володіти необхідними і достатніми ресурсами для відтворення креативної людини та їі ефективного розвитку, що торкається соціальної царини людини.

Виклад основного матеріалу. Здійснено аналіз становлення і розвитку креативної особистості як головного чинника освіти; представлено визначення «креативної особистості»; доведено, що креативна складова $\epsilon$ домінантою, необхідною для вирішення проблем ефективності всіх сфер діяльності, включаючи економічну; проаналізовано умови, що сприяють зростанню креативного складника в майбутньому; виявлено, що являє собою «креативний соціальний клас» як новий клас інформаційного суспільства. Об'єкт дослідження - концепт креативної особистості як новий соціальний і культурний феномен. Предмет дослідження - вплив інформаційного суспільства на становлення i розвиток креативної особистості. Методологія - методологія культуротворчості, що дає можливість для становлення i розвитку креативної особистості.

Висновки - сформовано концепцію освіти як чинника становлення i розвитку креативної особистості в умовах інформаційного суспільства.

Ключові слова: освіта, креативна особистість, творчість, компетентності, інформаційне суспільство, «новий креативний клас»

НИКИТЕНКО, В. А. - кандидат философских наук, доцент кафедры украиноведения и общественно-философских наук, Запорожская государственная инженерная академия (Запорожье, Украина)

E-mail: vitalina2006@ukr.net, ORCID: 0000-0001-9588-7836

\section{ОБРАЗОВАНИЕ КАК ФАКТОР СТАНОВЛЕНИЯ И РАЗВИТИЯ КРЕАТИВНОЙ ЛИЧНОСТИ В УСЛОВИЯХ ИНФОРМАЦИОННОГО ОБЩЕСТВА}

Аннотация. Актуальность исследования в том, что проанализировано образование как фактор становления и развития креативной личности и условия, которые способствуют появлению «невого креативного класса».

Постановка задания - концептуализация образования как фактора становления и развития креатвиной личности, основные ее категории в измерении «креативности» и востребованности человека как креатора инновационной среды, в основе которой новый уровень взаимодействия «человек-общество-образование», что изменеят модели социальности. Анализ последних исследований и публикаций. В исследовании мы 
опираемся на феномен креативности, который исследуется в работах В.Андрущенко, В, Беха, В.Воронковой, А.Кравченко, С.Куцепал, О.Кивлюк, Р.Олексенко. Главное внимание сосредоточено на работе Ричарда Флориды» «Ноmo creatives: Как новый класс завоевывает мир» (Киев, 2018). Матрица образования как фактора становления и развития креативной личности актуализирует внимание на дискурсосмыслении взаимоотношений «креативная личность-образование» и влияния информационного общества на эти взаимоотношения.

Выделение неисследованных частей общей проблемы - концептуализация понятия «креативная личность» и ее роль в современном информационном обществе.

В основе исследования - концептуализация базисных схем креативнсоти, которая представляет собой научную новизну. Эпистемологический характер постановки и праксиологическое решение данной проблемы на пользу креативной личности и образования свидетельствуют, что соцум должен владеть необходимыми и достаточными ресурсами для воспроизводства креативной личности и ее эффективного развития, что касается социальной основы личности.

Изложение основного материала. Исследован анализ становления и развития личности как главного фактора образования; представлено определение «креативной личности»; исследовано, что креативная составляющая есть доминатой, необходимой для решения проблем эффективности всех сфер деятельности, включая экономическую; проанализированы условия, которые содействуют увеличению креативной составляющей в будущем; исследовано, что предстваляет собой «креативный класс» как новый класс информационного общества. Объект исследования- концепт креативной личности как новый социальный и культурный феномен. Предмет исследования - влияние информационного общества на становление и развитие креативной дличности. Методология - методы культуротворчества и синергетики, которые дают возможность для становления и развития креативной личности.

Выводы - сформирована концепция образования как фактор становления и развития креативной личности в условиях информационного общества.

Ключевые слова: образование, креативная личность, творчество, компетентности, информационное общество «новый креативный класс»

Стаття рекомендована до публікачії д.філософ.н., проф. О. П. Пунченко (Одеса, Україна)

Надійшла до редколегіï: 10.10.2018

Прийнята до друку: 15.10.2018 